\title{
海産動物飼育海水の循環沪過式浄化法 に関する研究一IV.
}

\section{飼育魚による海水の污濁，および循環沪過式飼育 水槽の安全収容量}

\author{
平山和次 \\ (1965 年 9 月 27 日受理)
}

\section{STUDIES ON WATER CONTROL BY FILTRATION THROUGH SAND BED IN A MARINE AQUARIUM WITH CLOSED CIRCULATING SYSTEM-IV. \\ RATE OF POLLUTION OF WATER BY FISH, AND THE POSSIBLE NUMBER AND WEIGHT OF FISH KEPT IN AN AQUARIUM.}

\section{Kazutsugu Hirayama*}

In previous reports ${ }^{2 / 2) 51}$, the relation between purification of breeding water of an aquarium with closed circulating system, structure of a filter and filtering velocity was studied by using the oxygen consumption during filtration (OCF) as an index in evaluating the degree of purification.

If fish are kept well in an aquarium for a long time, a balance must be established between purification of breeding water by filtration and pollution by excretion of fish and by feeding. Therefore, the oxygen consumption during filtration corresponds to the rate of pollution of breeding water.

The present studies were carried out to find out the change in the rate of pollution by fish cultured with or without feeding. Sea breams, Chrysophrys major were cultured in an experimental aquarium (Fig. 1), and $O C F$ per unit time ( $\mathrm{mg} / \mathrm{min}$ ) were measured under various culturing conditions.

The rate of pollution expressed in OCF ( $X \mathrm{mg} / \mathrm{min}$ ) was found to have the following relation to the body weight of fish $(B \mathrm{~g})$ and to the amount of food per day ( $F \mathrm{~g} / \mathrm{day})$ :

where $q$ is the number of fish.

$$
X=\sum_{j=1}^{q}\left(B_{j}^{0.544} \times 10^{-2}\right)+0.051 F,
$$

From results of previous ${ }^{3 /}$ and present studies, fish cultured in an aquarium must be kept well for a long time, if the following relation holds in that aquarium:

$$
\sum_{i=1}^{p} \frac{10 W_{i}}{\frac{0.70}{V_{i}}+\frac{0.95 \times 10^{8}}{G_{i} D_{i}}} \geqq \sum_{j=1}^{q}\left(B_{j}{ }^{0.544} \times 10^{-2}\right)+0.051 F,
$$

where $W, V, D, G$ and $p$ represent area of filter bed $\left(\mathrm{m}^{2}\right)$, filtering velocity (cm/min), sand depth $(\mathrm{cm})$, grain-size coefficient ${ }^{3 \neq}$ and number of filter respectively. This relation was confirmed experimentally.

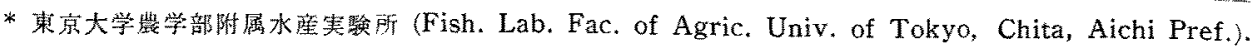




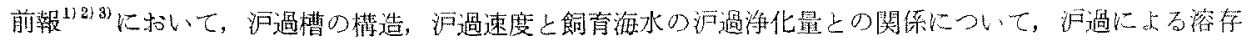
醉素の減少量 (oxygen consumption during filtration (OCF)) を沪過海化量の指標として研究した。本郝

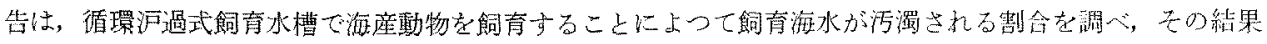

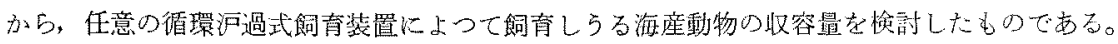

な山，海水の水丝分析の方法は前報”上同橡である。

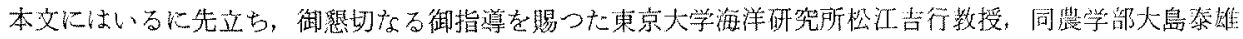
教授，および同海洋研究所多賀信夫助教授に感謝する。また，本研究陦施中，著者が勤務していた神户市立

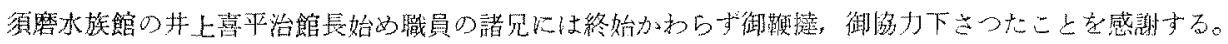

\section{海浑動物を飼育することによる海水の污濁}

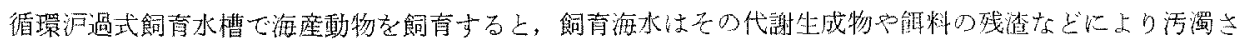

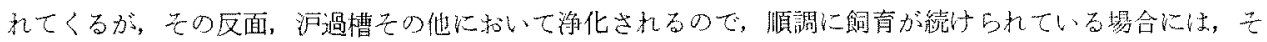

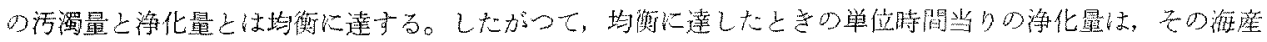
動物を飼育することによつて生ずる単位時間当りの污濁量飞等しい上考えられる。をこで, 飼育海水の污濁

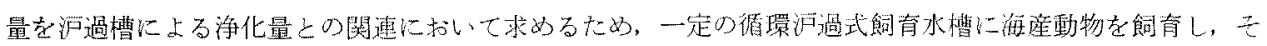
の沪過槽炕かかる負荷至調べた。

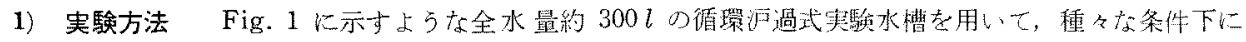
海産動物索飼育し，飼育海水の污澷度が一定になり水 質が平衡飞達しだときの沪過に上る単位時間当りの 浄化量, OCF $(\mathrm{mg} / \mathrm{min})$ を污濁量の指摽として测定 した。使用した汇過槽は赫報》゙で用いなものだ，その 内面樍 $300 \mathrm{~cm}^{2}$, 砂風の厚さは $40 \mathrm{~cm}$ である。沪砂 には粒径保数 $(G)^{* *} 102.4$ のむのを用い, 沪過速度 $3.5 \mathrm{~cm} / \mathrm{min}$ で汇過した。店拉, 飼育海水は須磨水族 館で実際に使用している海水 (水温注約 $20^{\circ} \mathrm{C}$, 塩溸

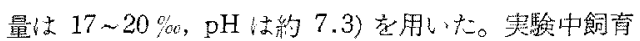
水槽には十分通気し, 蒸発江上る铝育海水の減少は適 宜に水道水に上り補立した。以下寒験方法の詳細につ いては，その都度述べることにする。

\section{2）飼育動物の代謝による污濁}

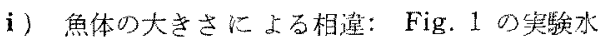
槽化健康なマダイ Chrysophrys major TEMMICK et SCHLEGEL 1 尾收容し, 飼育開始後飼育海水の水質 が平衡に澾した後, 1 日1回, 午前 10 時に洰過槽に かがる負荷（単位時間当りの OCF）を睍定した。2 5 日間の测定値の平均値をもつて，そのマダイの代鹊 生成物に上る污溜量とした。

沪砂は塩酸で十分洗淨したものを用い，まず $180 \mathrm{~g}$ のマダイを収容し，日を追つて nitrite-N を測定し

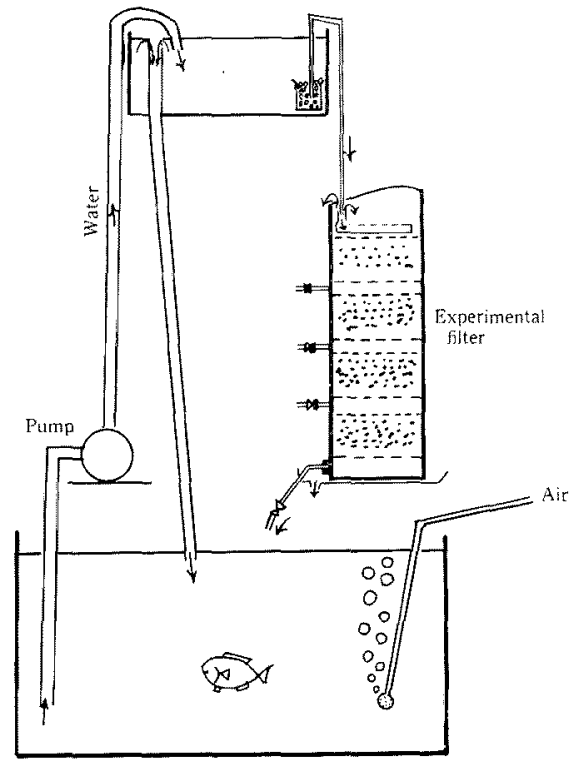

Fig. 1. Experimental aquarium with closed circulating system, Total volume of water is $300 l$. た。 nitrite は ammonia の nitrate への酸化 (硝化作用) の中間生成物であるからっこれが一定の濃度に

*長期間铜育を続けると，その飼育海水は少しずつ変化してくるが，短期閒でみれば平衡に達すると考 えてさしつがない。

** 前報光参照 
なつたときに活渴量上海化䁷は均衡に達していると考えられる故，てれが一定量となつたときをもつて沪

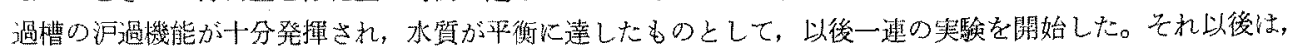
各大きさのマダイをいれか立る場合も汇砂を強く洗浄することなく, 必要に応じて敏水で軽く洗浄するのみ にとどあ，飼青海水の水筫が平衡に達するのを待つて次の測定を開始した。使用したマダイは赛験開始約 1 週間前上り触止めし，穾駼中も投触を行なわなからた。

体重の異なるマダイを飼育することにより沪過槽にかかる負荷（単位時間当りの OCF）は Fig. 2 に示 した通りである。

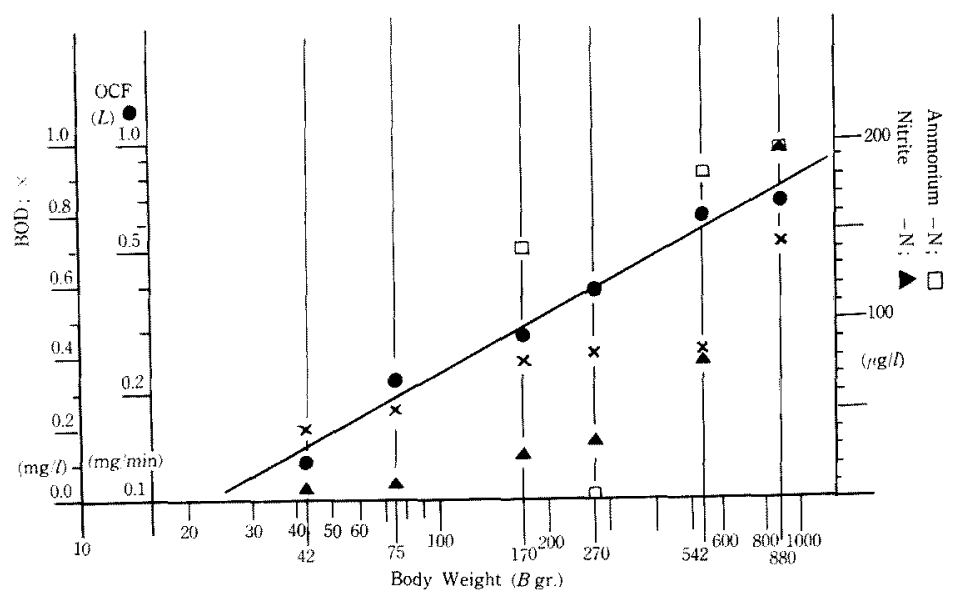

Fig. 2. Relation between the oxygen consumption during filtration (OCF), the concentrations of some chemical constituents in breeding water and the body weight of a fish kept in the experimental aquarium without feeding. OCF per unit time changes with the body weight of the fish as follows: $\log L=0.544 \log B-1.739$, where $L$ and $B$ represent $\mathrm{OCF}(\mathrm{mg} / \mathrm{min})$ and body weight $(g)$ respectively. Filtering velocity was maintained at $3.5 \mathrm{~cm} / \mathrm{min}$.

循環沪過式飼育水槽において，文の水質浄化火は水槽壁などによる浄化や海水の自浄作用なども関係して いるがこれらの浄化量は沪過浄化量に比校すればこの実駼水槽ではそれはど大きくないと考えられる*。 したがつて，ここに測定された単位時間当りの洰過浄化量 $(\mathrm{OCF} \mathrm{mg} / \mathrm{min})$ は各々の魚の代謝量の相対的な 值を示していると考兄られる。魚の体重と代謝骨との関係は，その酸素消費量を指摽として研究されており， 両者の対数値は直線関係にあることが知られている゙!。体重と単位時閒当りの OCF $(L)$ の両者の対数値を とると，Fig.2にみられるように，やはり両者の間以は直線関倸が成立し，その関保式は次式により示さ れる。

$$
\log L=0.544 \log B-1.739
$$

ただし，Lは OCF (mg/min)，Bは体重（g)である。采た，同時に测定した飼育海水の5 日間 BOD， ammonium-N, および nitrite-N の平均㨁も Fig. 2 に併示したが,これらもむた，体重の增大とともに 增加した。

ii）収容尾数於よび魚種に上る相椲：マダイを2尾以上同時に飼育した場合，その沪過槽に和外る浄化 量（OCF）を指標として测定した代謝量が，それぞれ1尾ずつの代謝量の和として求めてさしつか古ないか

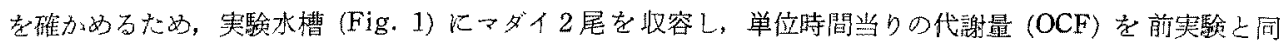

\footnotetext{
*末発表。
} 
Table 1. Changes in the oxygen consumption during filtration (OCF) with the changes in number and species of fish kept in the experimental aquarium.

\begin{tabular}{c|c|c|c|c|}
\hline Species & $\begin{array}{c}\text { Body weights } \\
\text { (g) }\end{array}$ & $\begin{array}{c}\text { Number of } \\
\text { observation }\end{array}$ & $\begin{array}{c}\text { Mean OCF observed } \\
\text { (mg/min })\end{array}$ & $\begin{array}{c}\text { OCF calculated* } \\
\text { (mg/min) }\end{array}$ \\
\hline Chrysophrys & 122 and 92 & 2 & 0.45 & $0.25+0.21=0.46$ \\
Chrysophrys & 880 and 1250 & 1 & 1.51 & $0.73+0.88=1.61$ \\
\hline Epinephelus & 188 and 129 & 2 & 0.26 & $* * 0.31+0.26=0.57$ \\
\hline
\end{tabular}

* Calculated from relation between OCF and body weight of fish (Formula 1).

** Calculated as Chrysophrys..

様な万法に上り測定した。次に，その1尾当りの代謝量をそれぞれ(1) 式上り計算し，両者の和と察测值上 を比較した。結果は Table 1 にみられるよ5に計算値上実湘值估極めてよく一致している。2 尾以上同時 に飼育した際の污濁量，すなわ污過槽にかかる負荷は，1 尾ずつについて(1) 式上り計算し，それらの 和上乙て求文ら机ることがわかる。

魚類の代謝量は，その体重ばかりでなく，魚種によつても異なるので，当然代謝生成物による污濁量，す

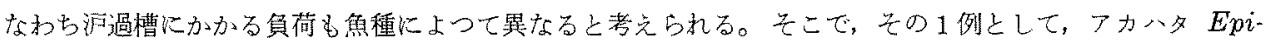
nephelus fasciatus (FoRSKAL) を飼育することによる沪過槽にかかる員荷を求る、マダイのそれと比䡆し

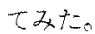

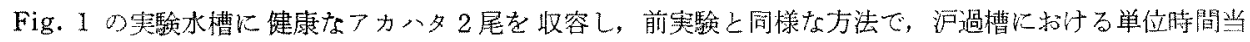
りの浄化量 (OCF) を湘定した。その結果はTable 1 た游示したとおりで, 同じ水椹に同体重のマダイ 2 虐を収容した場合に比較し非常に少ない。以上のょらに沪過槽にかかる焦荷は，飼育する魚の大小，魚種に

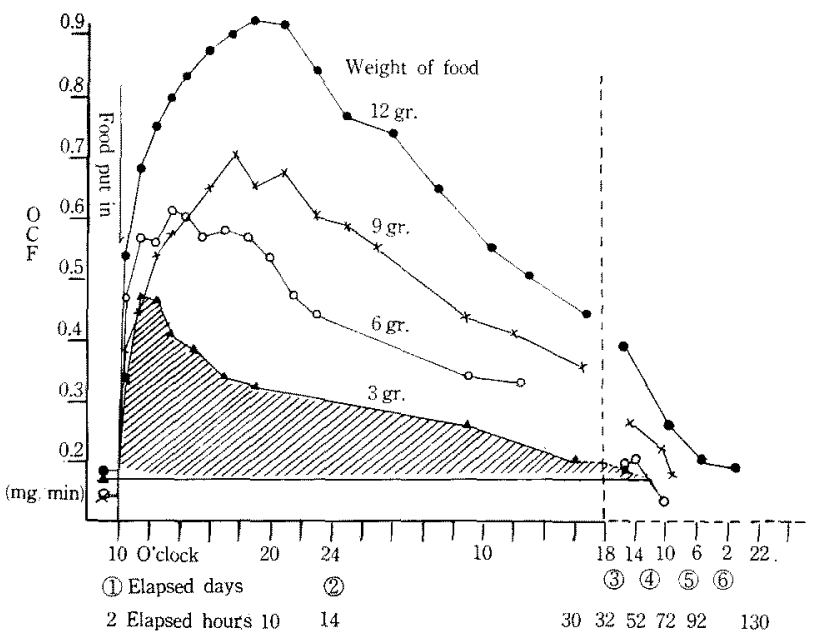

Fig. 3. Change of OCF value per unit time obtained by filtration of the aquarium water polluted by addition of various amounts of food to the water without being taken by fish.

Weight of food in each experiment is shown by wet weight.

1/III: Total OCF (mg) obtained from the filter loaded by $3 \mathrm{~g}$ of uneaten food. 
よつて著しく異なることがかかる。

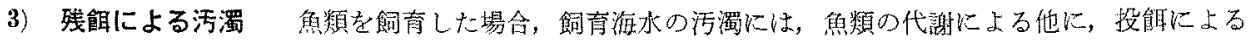
影響を考光なければならない。投能の影響としては，魚がをれを椇取することにより代謝量が增大すること，

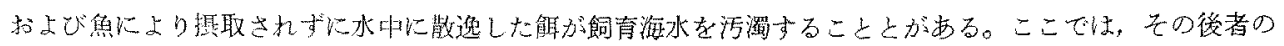
場合飞つき祝討与る。

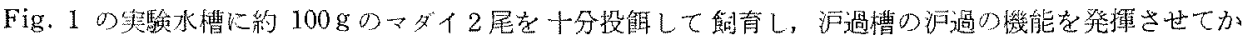
ら魚を取り除き，飼育海水のみにした。飼育海水を 5 日䦥，偱環洰過浄化した後に，十分粉础した新鮮なマ

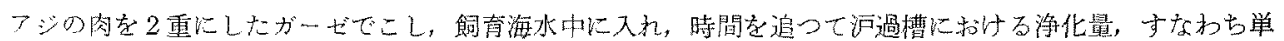

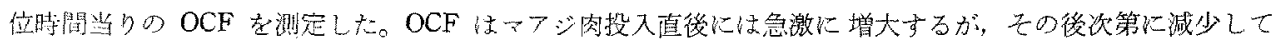
再ざ投入前の值にまで低下寸る。その経過はFig. 3 に示した通りで, マアシ肉段入後に汇過槽中で溶存酸 素が大きく減少するのは，マアジ肉に上り污攞された海水を浄化するのに溶存酸素が使用されるためである と考元られる。以上の結果から，マアジ肉を投入したことにより沪過槽にかかる負荷の総量, すなわち溶存

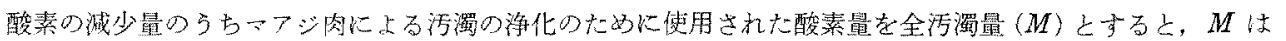
3gのマフシ肉を投入した例ではFig. 3 の斜線で囲交れた面積に上り示される。

今，かりに每目一定量ずつ散冕する残能がある場 台を考克てみる凶，残鲰に上る活濁を海化するため に，沪過槽ではその全污溜量 $(M)$ が每日浔化され なければならない。したがつて，杂杂を単位时間当 りの平均 $\mathrm{OCF}(\mathrm{mg} / \mathrm{min})$ にな找与と $M / 24 \times 60$ に なる。この上らにして求めた値を $a(\mathrm{mg} / \mathrm{min})$ 上 L，1 日当りの残䁈量老 $F(\mathrm{~g} / \mathrm{day})$ 上寸ると，両 者の周保はFig. 4 に黑丸で示したようになり，直 線関倸が成立し, その関倸式は

$$
a=0.0908 F-0.082
$$

て东されることが和る。

$9 \mathrm{~g}$ のアアジ肉投入した際の海水の水筫変化は， BOD は投入南後に最高值 $3.62 \mathrm{mg} / l$ を示し，以後 次第に娍少してゆくのに反L，ammonium-N は投 入後次第に增加して吅，11時間後には $158 \mu \mathrm{g} / \mathrm{l}$

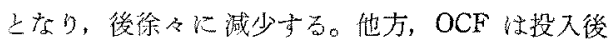
急激に增大山劣るが，7.5 時間後に最高倠 $0.71 \mathrm{mg}$ / mink澾し，以後減少した。この上らに各水留条 件の变化下時閵的なずれが生したのは，まず初いに 有機物の分解方起こり，无机方ら硝化作用方治まる ためですると考克られる。

4）投餌して飼育することによる活濁 以上， 海水奥の代謝，おょび残能による䬼育海水の污濁に

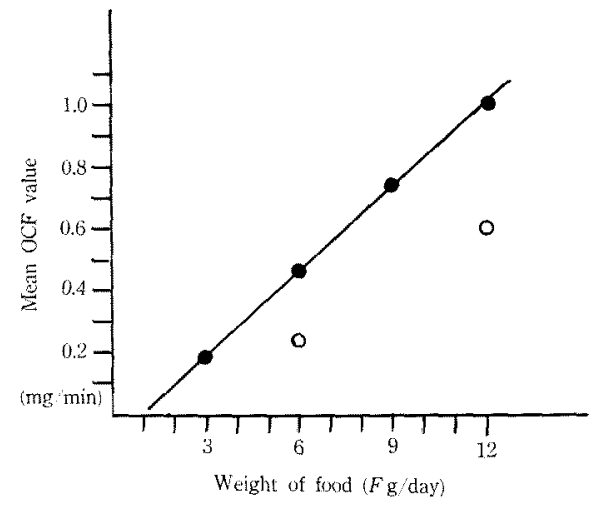

Fig. 4. Relation between amounts of food per day and mean OCF value per minute with which the filter was loaded only by food.

- Mean OCF value (a) when food remained in the water without being taken by fish.

$O$ : Mean OCF value $\left(a^{\prime}\right)$ when fish took food. Mean OCF value of $a^{\prime} / a$ calculated from $O C F$ data at the experiments in which the same weight of food was added: 0.56 .

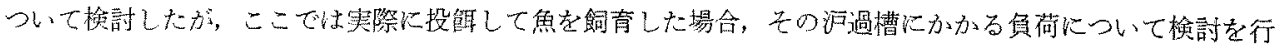
なつた。

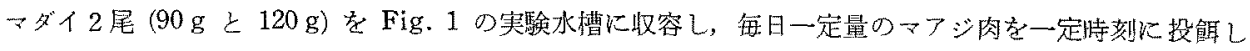

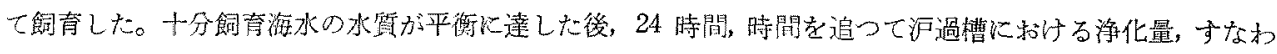
らこれらを飼奇することにより洰過槽にかかる負荷を単位時間当りの OCF を测定することにより求めた。

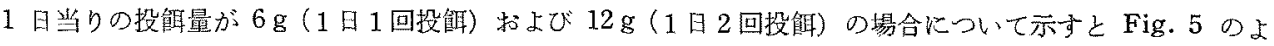


うになる。12 $\mathrm{g}$ 投䬣の際の飼育海水の BOD の变動は，投饂前 9 時 30 分には $0.59 \mathrm{mg} / l$ であつたが, 21 時沈法 0.84 $\mathrm{mg} / l$ に增大し, 次の日の 9 時 30 分に は $0.49 \mathrm{mg} / \mathrm{l}$ Kなつた。他方, ammonium-N は21 時记は $260 \mu \mathrm{g} / \mathrm{l}$ とな りかなりの増大がみ上められた。

無投䬣で飼育した場合上投跳して飼育 した場合上では，告の飼育海水の污濁心 質的な差がある。したがつて，沪過槽内

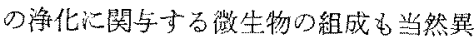
なつていることが考えられる。そこで， 本害駼上継続して，同じ 2 尾のマダイを 埕育海水の及新しい海水儿加克て無投 䬲で飼育し，4 日後上り1日 1 回単位時 間当りの OCF 測定したところ，4回 の平均値法 $0.25 \mathrm{mg} / \mathrm{min}(0.26,0.22$,

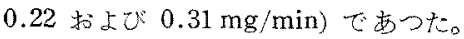
この値を無投慨で飼育し沪過機能の熟成 をはからた時の単位時間当りの OCF 上 魚の体重之の関保式 (1) より求めた值 $0.46 \mathrm{mg} / \mathrm{min}$ 乙比较すると非常に小さ く苟 $55 \%$ にすぎない。この原因につい ては追究できなかつたが，いずれにして b，無投䭒で沪過機能を熟成した場合之 投慨した場合上では，洰過槽の浄化效率 が異なることが考えられる。

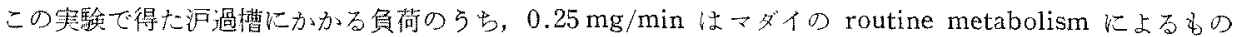
とし，兑れより多い部分は慨を魚が掑取したことにより代謝量が增大しそれが沪過槽の負荷になること，お

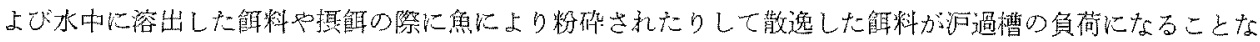

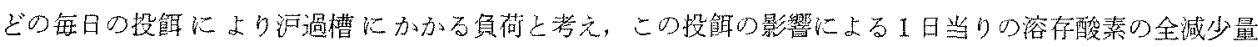

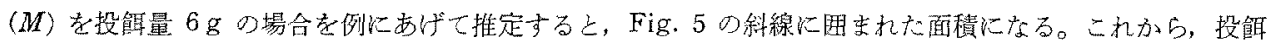

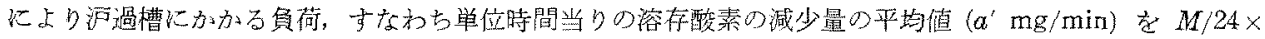

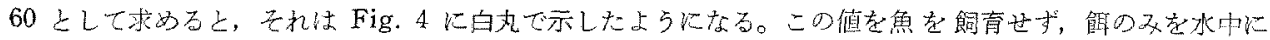

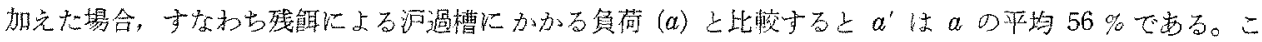
の上5に投期し魚がそれを摂取した場合には，掑取しなかつた場合上比較して沪過槽にかかる負得が小さく なるのは, 摄取されだ触が魚の体内で消化分解され，きらにその一部は体保保持されるので，沪過槽にかか る負荷がそれだけ軽減されるためであるう。

\section{安全収容量}

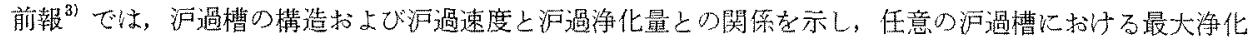
皇が単位時間当りの OCFに上り求められることを示した。他方，魚を飼育することにより洰過槽にかかる 負荷は，その魚種，体重，飼育尾数，および投䬣量によつて異なるこ之は前述の通りである。ある循環沪過 


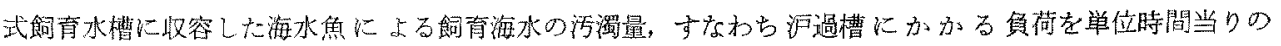
OCF で求めた健を $X \mathrm{mg} / \mathrm{min}$ とし，この飼育水槽の $p$ 個の汇過槽について求めた最大洗化量をそれぞ れ $Y_{1}, Y_{2}, \cdots Y_{p}$ とすれば, 两者の間に $\sum_{i=1}^{P} Y \geqq X$ の関係が成立するならば, その飼育水槽で,これらの

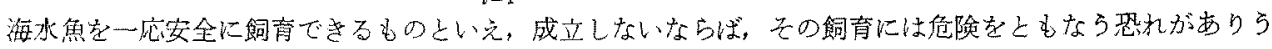
ることを示していると考兵られる。

循環沪過式飼育法での安全收容量は，收容する魚種によりその代謝量和よび飼育海水の水質の污濁に対す る抵抗性む異なるので一律には諭じられない。をこで。ここでは一応、ダイを海水魚の代表として選び，マ ダイについて得られた知見からをの安全収容量について検討した。

マダイを無投邻て飼育した際のをの代謝による活濁，すなるち単位時間当り OCF と体重との関倸は (1) 式に示した通りである。普通に投餉して飼育し沪過槽を熟成した埸合には, routine metabolismに上り沪 渦槽にかかる負荷 (OCF) は，無投䬺で飼育した場合の約 $55 \%$ *になるのであるから，任意の大きさのマ ダイ $q$ 尾を䬨育した時, その体重をそれぞれ $B_{1}, B_{2} \cdots B_{j} \cdots B_{q}(\mathrm{~g})$ とし, routine metabolismに上り沪 過槽にかかる負荷を $L^{\prime}$ とす机ば（1）式上り，

$$
L^{\prime}=L \times 0.55=\sum_{j=1}^{q} B_{j}^{0.544} \times 10^{-2}
$$

で示すことができる。

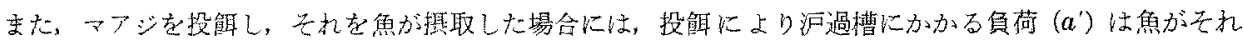

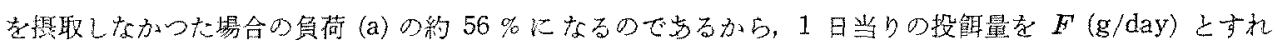
ば, $a^{\prime}(\mathrm{mg} / \mathrm{min})$ は (2) 式上り

$$
a^{\prime}=a \times 0.56=0.051 F-0.046
$$

になる。

したがつて，マダイにマアジを投慨して飼有した場合の汇過槽にかかる負荷 $X(\mathrm{mg} / \mathrm{min})$ は，京の収容 量执よび投饂量が共に極端に小さい場合を除いては（4）式右辺第2 項は無視できるから (3) (4) 式より

$$
X=L^{\prime}+a^{\prime}=\sum_{j=1}^{q}\left(B_{j}^{0.544 \times 10^{-2}+0.051 F}\right.
$$

で示される。

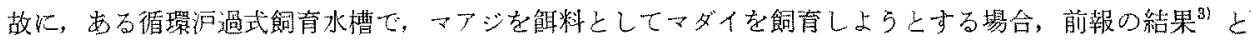
(5) 式とより,

$$
\sum_{i=1}^{n} \frac{10 W_{i}}{\frac{0.70}{V_{i}}+\frac{0.95 \times 10^{3}}{G_{i} D_{i}}} \geqq \sum_{j=1}^{q}\left(B_{j}^{0.544} \times 10^{-2}\right)+0.51 \mathrm{~F}
$$

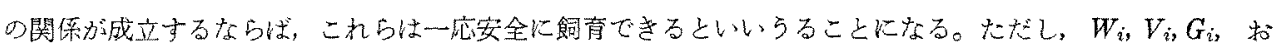

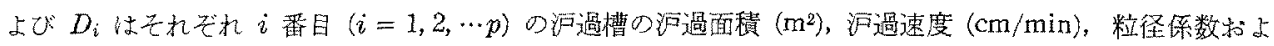
び砂層の厚さ $(\mathrm{cm})$ を示している。

(6) 式は，マダイを飼育する場合の安全収容量を示したものであるが，一応これを循環沪過式飼育法で海 水魚を飼育する場合の安全収容量，設計基準の目安とすることができよう。

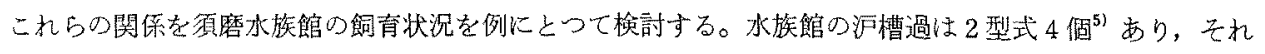
らについての最大浄化量** (OCF) を(6)式より求めると, 合計 $902 \mathrm{mg} / \mathrm{min}$ になり, 1 時間当りの浄化量 飞換算すると $54120 \mathrm{mg} /$ hour になる。他方, 实際にこの 4 個の沪過槽に和ける沪過による溶存酸素の減少 量を調查したところ，約 $52800 \mathrm{mg} / \mathrm{hour}^{5 !}$ になり，雨者はよく一致する。さらに水族館に体重 $100 \mathrm{~g} の マ$

* $55 \%$ というの泣 $90 \mathrm{~g}$ と $120 \mathrm{~g}$ のマダイを飼㕕した場合に得られた值で, 体重が異な机ばこの值も異 なつてくるこ上も考光られるが，他江实唤例がないのでこの值を使用した。

**使用している挶砂の有効径 0.7 を粒径の代表值として粒径保数 $(G)$ を計算した。 


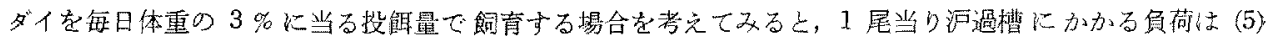
式より $0.28 \mathrm{mg} / \mathrm{min}$ と得られるから，水族館では約 3200 尾 $(320 \mathrm{~kg})$ 束で怯安全に飼育しらることにな る。本実験中，須磨水族館では大小各種とりまぜ（旅がメ類を除く）200 300 kg を常時飼育していたので あるからこの佔は一応妥当なるのとい兑よう。

\section{考察}

以上，極めて概括的で岋あるが，循環汇過式飼育法に上り海水魚老飼育する場合の安全収容量を求める力 法を示したが，この安全收容量は一つの目安を示寸すのであることはいらまですない。(6)式の右讱はマダ イにヤアシ肉を投慨しな場合を代表として飼育海水の污濁量を求めた值であるから，他種の海産動物を他の 䬣で飼育する場合には，当然その代謝量お上び投饂の影響が異なつてくるのでこの点については別に検討し

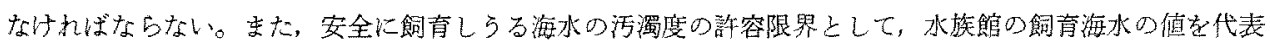

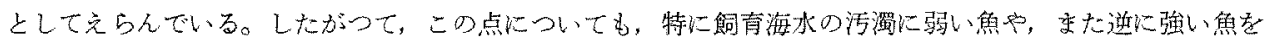
飼育する場合には考慮しなければならないことはいら恋でるない。

また，飼青海水の自浄作用や，水槽壁その他に附着発育した微生物に上る海化の効果については特治馀討 を加克ていないが，この実験で使用した水慒に执いても飼育することにより沪過槽にかかる負荷は，これら

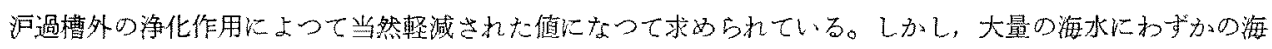

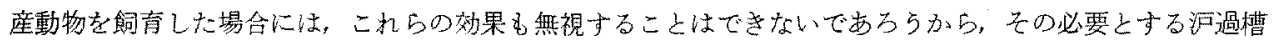
の構造などは(6) 式に上り求められるもの上は違つた値になるであるう。さらに水槽壁などに藍藻，硅藻な どか繁茂した場合には，一屬椲つてくると思呩れ。

本研究に㧍いては，沪過浄化の効果は沪仯の表面に附着発育した徽生物の浄化作用にのみよるとした。し が，非常に沪過速度が小さい場合や，大きい粒径の沪砂を使用した場合などは，沪床の閉塞が起こらず， 沪過槽の管理作業を長期間にわたり行なわないために，次第に沪砂の間隐にも微生物が発育し，それが飼育 海水の浄化に関与して，安全収容量は，(6) 式で求めた优上り大になることが考壳られる。

また，この一連の实験は，約 80 日に1度しか新しい海水に取替之ない水族館の飼育海水に上り行なつた。 したがつて，飼育海水をひんぱんに新しい海水にとりか支る場合はこれまた条件は違つてくる。

さらに，この安全収容量の推定は水質の海化の面上り追究したのでありて，通気不十分に上る酸素不足や， 生態的な安全収容密度, 水槽内の水の交流などの条件に上つて収容悬が制限されることも十分考えられ，こ れらの点を考虑すれば安全收容量は一層複雑なものになるであるう。

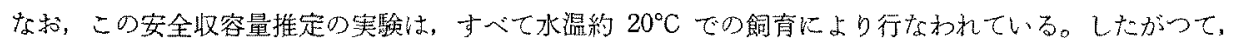
飼育水温が極度に異なる場合にはをの代謝量, 浄化量が異なつてくるため, この点についての考慮も必要に なる。

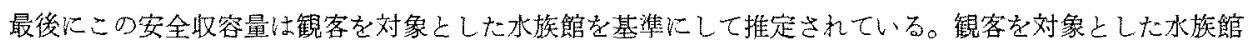

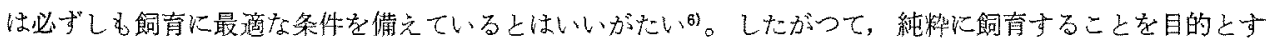
る場合に怯この点をも考慮しなければならないであるう。

\section{文銤}

1) 平山和次：本誌， 31，977 (1965).

2) ——: - 31, 983 (1965).

3) —_. 32, 976 (1966).

4) FRY, F.E.J.: The aquatic respiration of fish. In: The Physiology of Fishes, vol. 1, Brown, M. E., ed. N. Y., Academic Press, 1 63. (1957).

5) 平山和次：水産增殖，8，123(1960)。

6) _—_ - _ — , 臨時号 1, 43 (1962). 